\title{
SOSIALISASI PEMILIH PEMILU DI SEKOLAH MENENGAH KEJURUAAN MELALUI PENGGUNAAN ADOBE FLASH
}

\author{
Hazizah, Fadilah, Aloysius Mering, \\ Magister Teknologi Pendidikan, FKIP Universitas Tanjungpura Pontianak. \\ Email: hazizah82@yahoo.com
}

\begin{abstract}
The aims of this research were to determine: (1) the message design that would be used in the development of adobe flash for the socialization of vocational students in Sintang, (2) the implementation of the message design that would be used in the development of adobe flash for the socialization of vocational students in Sintang, (3) Interest in participating in the general election of SMK students in Sintang, (4) Awareness and positive attitude of SMK students in Sintang towards the election after using Adobe Flash. This research is a development research using the Borg \& Gall development procedure. Data obtained from interviews, observations, questionnaires and documentation. The results showed that: (1) the design of adobe flash for the socialization of vocational students in Sintang was carried out through the Borg and Gall stages, (2) the implementation of the socialization of vocational students in Sintang using adobe flash was included in the very appropriate category, (3) the interest of vocational students in Sintang towards the election after using adobe flash is in the good category, and (4) the critical attitude of vocational students in Sintang has raised awareness and a positive attitude towards the election after using adobe flash is in the very good category. Therefore, it is hoped that the government will program socialization media that can attract SMK students in Sintang to take part in the election.
\end{abstract}

\section{Keywords: Election Voter Socialization, Vocational Middle School, Using Adobe Flash}

\section{PENDAHULUAN}

Minat adalah hal yang sangat penting dalam segala hal. Begitu juga dalam pemilihan umum, minat sangat berpengaruh pada partisipasi pemilih yang akan menggunakan haknya dalam pemilihan umum, tidak terkecuali para siswa di sekolah menengah kejuruan (SMK) di Sintang yang baru pertama kalinya mengikuti proses pemilihan umum ini.

Pemilih dalam pemilu adalah hal yang sangar penting guna keberlangsungan pemilihan umum tersebut bagi negara yang menganut sistem demokrasi. Begitu juga Siswa di sekolah menengah kejuruan (SMK) di Sintang mempunyai peran yang penting dalam upaya menjalankan roda pemerintahan dimasa yang akan datang. Oleh karena itu pelaksanaan sosialisasi tentang pelaksanaan pemilihan umum harus dilakukan dengan cara yang baik dan tepat agar para siswa di sekolah menengah kejuruan (SMK) di Sintang mempergunakan hak suara mereka dan berpartisipasi dalam politik.

Menurut hasil obesrvasi di sekolah menengah kejuruan (SMK) di Sintang, peneliti mendapatkan data bahwa minat para siswa yang merupakan siswa di sekolah menengah kejuruan (SMK) di Sintang dalam pemilihan umum kurang baik, bahkan banyak siswa tersbut tidak mau sama sekali ikut berpatipasi dalam pemilihan umum. Hal ini dikerenakan siswa di sekolah menengah kejuruan (SMK) di Sintang mempunyai pengetahuan yang sedikit tentang pemilihan umum atau bahakan di sekolah menengah kejuruan (SMK) di Sintang tidak mengetahui sama sekali tentang pelaksanaan pemilihan umum yang dilaksanakan oleh KPU yang dilaksanakan 5 tahun sekali dengan system demokrasi. 
Meskipun jumlah siswa di sekolah menengah kejuruan (SMK) di Sintang tidak banyak dibandingkan para pemilih lainya, akan tetapi kurangnya minat di sekolah menengah kejuruan (SMK) di Sintang terhadap politik itu tentu akan sangat berpengaruh dan berimbas pada keterlibatan para siswa di sekolah menengah kejuruan (SMK) di Sintang karena mereka sebagi pemilih. Oleh karena itu untuk meningkatkan kembali minat siswa di sekolah menengah kejuruan (SMK) di Sintang agar mereka dapat berpartisipasi dan menyalurkan hak suaranya maka KPU mengadakan agendaagenda sosialisasi pemilihan umum.

Dalam pelaksanaan sosialisasi pemilihan umum kepada para siswa di sekolah menengah kejuruan (SMK) di Sintang khususnya pada siswa di sekolah menengah kejuruan (SMK) di Sintang, KPU Sintang melaksanakan sosialisasi pemilu untuk siswa di sekolah menengah kejuruan (SMK) di Sintang khususnya siswa di sekolah menengah kejuruan (SMK) di Sintang dengan menggunakan media modul. Sosialisasi pemilu kepada siswa di sekolah menengah kejuruan (SMK) di Sintang dengan modul ini bertujuan agar dapat menjadi acuan dalam mengatasi masalah yang ada dalam siswa di sekolah menengah kejuruan (SMK) di Sintang yaitu kurangnya peran aktif dari siswa di sekolah menengah kejuruan (SMK) di Sintang dengan kata lain masih terjadinya pilihan golput pada siswa di sekolah menengah kejuruan (SMK) di Sintang yang merupakan pemilih yang sangat membutuhkan bimibingan untuk dapat berpatisipasi dalam pemilihan umum yang dilaksanakan oleh KPU.

Namun pelaksanaan sosialisasi pemilu yang dilaksanakan oleh KPU masih belum terlaksana dengan efektif dan maksimal, hal ini dikarenakan siswa di sekolah menengah kejuruan (SMK) di Sintang kurang tertarik untuk membaca media modul yang digunakan oleh KPU dalam sosialisasi pemilu.

Kurangnya antusias siswa di sekolah menengah kejuruan (SMK) di Sintang dalam mengikuti pelaksanaan sosialisasi menggunakan media modul berdampak pada minat siswa di sekolah menengah kejuruan (SMK) di Sintang dalam berpartispasi dan keikutsertaan mereka dalam pemilihan umum, yang akan berujung kurangnya jumlah siswa di sekolah menengah kejuruan (SMK) di Sintang yang mengikuti pemilihan umum.

Masalah tersebut apabila dibiarkan dan tidak dicarikan solusi untuk mengatasi masalah tersebut akan menjadi momok yang menakutkan bagi keberlangsungan demokrasi di Indonesia khusunya bagi siswa di sekolah menengah kejuruan (SMK) di Sintang dan bahkan bisa akan berkembang menjadi masalah yang lebih besar. Salah satu solusi yang dianggap tepat dalam masalah ini adalah dengan cara menggunakan media sosialisasi yang disukai dan menarik bagi siswa di sekolah menengah kejuruan (SMK) di Sintang yaitu menggunakan media sosilaisasi yang dekat dengan siswa adobe flash yaitu media berbasis IT seperti media adobe flash.

\section{METODE PENELITIAN}

Dalam penelitian ini peneliti menggunakan jenis penelitian pengembangan. Jenis penelitian pengembangan menurut Punaji (2010, p.277) adalah suatu proses yang dipakai untuk mengembangkan dan memvalidasi produk pendidikan dan pengembangan dapat berupa proses, produk dan rancangan. Prosedur pengembangan dalam penelitian menggunakan prosedur pengembangan Borg \& Gall yang dilaksanakan di SMK Muhammadiyah Sintang.

Dalam penelitian ini peneliti adalah instrumen utama dalam penelitian ini dikarenakan peneliti akan terjun langsung di lapangan untuk menemukan data penelitian. Dalam peneltian ini peneliti menggunakan alat pengumpul data, yaitu lembar observasi, panduan wawancara, kuesioner dan dokumentasi. Sedangkan teknik pengumpulan data yang digunakan dalam penelitian ini adalah teknik observasi, teknik komunikasi langsung, teknik komunikasi tidak langsung, teknik dokumenter.

Agar data yang telah didapat oleh peneliti memiliki kredibilitas yang tinggi dan menghindari kesalahan dalam menentukan hasil dalam penelitian ini maka peneliti melakukan pengecekan keabsahan data dengan cara meningkatkan ketekunan dalam melakukan observasi dan triangulasi. pengecekan keabsahan data adalah hal ini harus dilakukan 
oleh setiap peneliti setelah penelitian agar hasil penelitian memiliki hasil kredebilitas yang tinggi dan dapat diterima oleh semua pihak.

\section{HASIL PENELITIAN DAN PEMBAHASAN}

\section{Hasil Penelitian}

Desain pesan yang digunakan dalam pengembangan adobe flash untuk sosialisasi siswa di sekolah menengah kejuruan (SMK) di Sintang menggunakan langkah-langkah penelitian Borg \& Gall yang telah dilakukan sesuai dengan urutan pelaksanaanya. Untuk mengetahui kondisi awal tentang tempat penelitian peneliti melakukan observasi dan wawancara kepada guru PKn tentang pengetahuan siswa siswa di sekolah menengah kejuruan (SMK) di Sintang terhadap pemilihan umum. Dari hasil observasi dan wawancara tersebut maka peneliti melakukan analisis untuk menentukan langkah selanjutnya yang akan dilakukan. Hasil observasi dan wawancara ini adalah tahap yang sangat penting untuk mendapatkan dan mengetahui data sebelum dilaksanakan penelitian di lapangan oleh peneliti.

Setelah melakukan observasi dan wawancara awal, langkah selanjutnya yang peneliti lakukan adalah melakukan perencanaan dan mendesain produk awal dengan mendesain awal bahan sosialisasi Pemilihan Umum siswa di sekolah menengah kejuruan (SMK) di Sintang yang terdiri aspek tampilan dan aspek pemograman dan evaluasi yang didesain dengan memperhatikan kebutuhan siswa di sekolah menengah kejuruan (SMK) di Sintang.

Pelaksanaan sosialisasi siswa di sekolah menengah kejuruan (SMK) yang telah dilaksanakan oleh peneliti dilaksanakan melalui 3 tahapan yaitu: uji coba satu-satu, kelompok kecil, dan kelompok besar dan setiap uji coba tersebut siswa diminta mengisi angket tanggapan terhadap media, angket minat dalam mengikuti pemilihan umum dan angket kesadaran dan sikap positif terhadap pemilu yang telah disediakan oleh peneliti.

Dari hasil pelaksanaan uji coba tersebut maka peneliti mendapatkan hasil dari pelaksanaan sosialisasi. Adapun hasil dari pelaksanaan sosialisasi siswa di sekolah menengah kejuruan (SMK) di Sintang yang dilaksanakan oleh peneliti untuk mengetahui tanggapan siswa terhadap media yang digunakan dalam proses sosialisasi pemilihan umum adalah sebagai berikut:

Tabel 1. Hasil Angket Tanggapan Terhadap Media

\begin{tabular}{cccl}
\hline No & Tahapan Uji Coba & Nilai & Katagori \\
\hline 1 & Uji Coba Satu-Satu & 3,8 & Sangat Sesuai \\
\hline 2 & Uji Kelompok Kecil & 3,77 & Sangat Sesuai \\
\hline 3 & Uji Kelompok Besar & 3,74 & Sangat Sesuai \\
\hline
\end{tabular}

Selain angket tanggapan terhadap media, dalam peneltian ini peneliti juga menggunakan angket minat dalam mengikuti pemilihan umum. Adapun hasil dari pelaksanaan sosialisasi siswa di sekolah menengah kejuruan (SMK) di
Sintang di sekolah menengah kejuruan (SMK) di Sintang yang dilaksanakan oleh peneliti dilakasanakan melalui 3 tahapan dengan alat angket minat terhadap media yang dikembangkan adalah sebagai berikut:

Tabel 2. Hasil Angket Dalam Mengikuti Pemilihan Umum

\begin{tabular}{cccc}
\hline \multirow{2}{*}{ No } & Tahapan Uji Coba & Ya & Tinat Pemilih \\
\cline { 3 - 4 } & & $76,67 \%$ & $23,33 \%$ \\
\hline 1 & Uji Coba Satu-Satu & $77,78 \%$ & $23,33 \%$ \\
\hline 2 & Uji Kelompok Kecil & $79,26 \%$ & 20,74 \\
\hline 3 & Uji Kelompok Besar & \multicolumn{2}{c}{ Baik } \\
\hline \multicolumn{2}{c}{ Katagori Keseluruhan }
\end{tabular}


Adapun hasil rata-rata hasil angket kesadaran siswa di sekolah menengah kejuruan (SMK) di Sintang untuk menumbuhkan kesadaran dan sikap positif terhadap pemilu yang peneliti dapatkan berdasarkan hasil angket yang telah dibagikan adalah sebagai berikut:

Table 3. Hasil Angket Kesadaran Dan Sikap Positif Terhadap Pemilu

\begin{tabular}{cccc}
\hline No & Tahapan Uji Coba & Nilai & Katagori \\
\hline 1 & Uji Coba Satu-Satu & 3,67 & Sangat Sesuai \\
\hline 2 & Uji Kelompok Kecil & 3,74 & Sangat Sesuai \\
\hline 3 & Uji Kelompok Besar & 3,75 & Sangat Sesuai \\
\hline
\end{tabular}

\section{Pembahasan Penelitian}

Desain pesan yang akan digunakan dalam pengembangan adobe flash untuk sosialisasi siswa di sekolah menengah kejuruan (SMK) di Sintang menggunakan langkah-langkah penelitian Borg \& Gall yang telah dilakukan sesuai dengan urutan pelaksanaanya. Untuk mengetahui kondisi awal tentang tempat penelitian peneliti melakukan observasi dan wawancara kepada guru PKn tentang pengetahuan siswa siswa di sekolah menengah kejuruan (SMK) di Sintang terhadap pemilihan umum. Dari hasil observasi dan wawancara tersebut maka peneliti melakukan analisis untuk menentukan langkah selanjutnya yang akan dilakukan.

Setelah melakukan observasi dan wawancara awal, langkah selanjutnya yang peneliti lakukan adalah melakukan perencanaan dan mendesain produk awal dengan mendesain awal bahan sosialisasi Pemilihan Umum siswa di sekolah menengah kejuruan (SMK) di Sintang yang terdiri aspek tampilan dan aspek pemograman dan evaluasi yang didesain dengan memperhatikan kebutuhan siswa di sekolah menengah kejuruan (SMK) di Sintang.

Tahapan desain pesan yang akan digunakan dalam pengembangan adobe flash untuk sosialisasi siswa di sekolah menengah kejuruan (SMK) di Sintang telah sesuai dengan langkahlangkah penelitian Borg \& Gall, sehingga dapat menghasilkan desian pesan pengembangan media sosialisasi yang baik dan dapat menarik minat pengguna media. Hal ini sesuai yang dikemukan Sadiman dkk (2014), secara umum media mempunyai fungsi sebagai berikut: (1) memperjelas penyajian pesan agar tidak terlau bersifat verbalitas (dalam bentuk kata-kata tertulis atau lisan belaka) (2) mengatasi keterbatasan ruang, waktu dan daya indera, seperti misalnya: (a) objek yang terlalu besar bias digantikan dengan realita, gambar, film bingkai, film atau model, (b) objek yang teralalu kecil dibantu dengan proyektor mikro, film bingkai, film atau gambar, (c) gerak terlalu lambat atau terlalu cepat dapat dibantu dengan timelapse atau high-speed photography, (d) kejadian atau pristiwa yang terjadi di masa lalu bias ditampilkan lewat rekaman fim, video, film bingkai, foto maupun secara verbal, (e) objek yang terlalu kompleks (misalnya mesin-mesin) dapat disajikan dengan model, diagram,dan lain-lain, dan (f) konsep yang terlalu luas (gunung berapi, gempa bumi, iklim dan lainlain) dapat divisualisasikan dalam bentuk film, film bingkai, gambar dan lain-lain. (3) Penggunaan media pendidikan secara tepat dan bervariasi dapat mengatasi sikap pasif anak didik. Dalam hal ini media pendidikan berguna untuk: (a) menimbulkan kegairahan belajar, (b) memungkinkan interaksi yang lebih langsung anatar anak didik dengan lingkungan dan kenyataan, (c) memungkinkan anak didik belajar sendiri-sendiri menurut kemampuan dan minatnya, dan (d) dengan sifat yang unik pada tiap peserta didik ditambah lagi dengan lingkungan dan pengalaman berbeda, sedangkan kurikulum dan materi pendidikan ditentukan sama untuk setiap peserta didik, maka guru banyak mengalami kesulitan bilamana semuanya itu harus diatasi sendiri. Hal ini akan lebih sulit bila latar belakang lingkungan guru dan peserta didik berbeda. Masalah ini dapat diatasi dengan media pendidkan, yaitu dengan kemampuannya dalam memberikan perangsang yang sama, mempersamakan terhadap pengalaman dan menimbulkan persepsi yang sama.

Pelaksanaan sosialisasi siswa di sekolah menengah kejuruan (SMK) di Sintang di 
sekolah menengah kejuruan (SMK) di Sintang yang dilaksanakan oleh peneliti dilakasanakan melalui 3 tahapan yaitu: uji coba satu-satu, kelompok kecil, dan kelompok besar. Dari tiga tahapan uji coba tersebut, pada setiap tahapannya peneliti akan memberikan angket kepada siswa untuk mengetahui tanggapan mereka terhadap media yang mereka gunakan, minat mereka terhadap pemilu dan sikap kritis siswa di sekolah menengah kejuruan (SMK) di Sintang untuk menumbuhkan kesadaran dan sikap positif terhadap pemilu.

Berdasarkan hasil angket tersebut, maka diperoleh data bahwa rata-rata tanggapan mereka terhadap media yang mereka gunakan masuk dalam katagori sangat sesuai (SS), minat mereka terhadap pemilu masuk dalam katagori baik (baik) dan sikap kritis siswa di sekolah menengah kejuruan (SMK) di Sintang untuk menumbuhkan kesadaran dan sikap positif terhadap pemilu masuk dalam katagori sangat sesuai (SS).

Menurut Slameto (2010), Minat sangat besar pengaruhnya terhadap belajar, karena bila bahan pelajaran yang dipelajari tidak sesuai dengan minat siswa maka siswa tidak akan belajar dengan sebaik- baiknya, karena tidak ada daya tarik tersendiri baginya. Sehingga siswa enggan untuk belajar, salah satunya dikarenakan siswa tidak memperoleh kepuasan dari pelajaran itu kemudian menjadi bosan terhadap pelajaran tersebut.

Bahan yang dijadikan materi sosialisasi akan lebih menarik minat siswa, lebih mudah dipelajari dan disimpan karena minat mampu menambah kegiatan belajar yang aktif. Anak yang berminat terhadap sebuah kegiatan, baik permainan maupun pekerjaan, akan berusaha lebih keras untuk belajar dibandingkan dengan anak yang kurang berminat. Disamping itu, minat juga dapat mempengaruhi intensitas dan bentuk inspirasi anak. Ketika anak mulai berfikir mengenai pekerjaan mereka dimasa yang akan datang misalnya, mereka akan menentukan apa yang ingin mereka saat dewasa nanti. Semakin yakin mereka mengenai pekerjaan yang diidamkan maka semakin besar minat mereka terhadap kegiatan tersebut. Selain itu minat juga bisa menambah kegembiraan yang ditekuni oleh setiap orang.
Apabila siswa berminat pada suatu kegiatan, pengalaman mereka akan sangat jauh menyenangkan, namun jika anak tidak memperoleh kesenangan maka mereka hanya akan berusaha semampunya saja. Minat merupakan masalah yang penting dalam pendidikan, apa lagi dikaitkan dengan aktivitas seseorang dalam kehidupan sehari-hari. Minat yang ada pada diri seseorang akan memberikan gambaran dalam aktivitas untuk mencapai tujuan. Di dalam belajar banyak siswa yang kurang berminat dan yang berminat terhadap pelajaran termasuk didalamnya adalah aktivitas praktek maupun teori untuk mencapai suatu tujuannya. Dengan diketahuinya minat seseorang akan dapat menentukan aktivitas apa saja yang dipilihnya dan akan melakukannya dengan senang hati

Meningkatnya minat siswa di sekolah menengah kejuruan (SMK) di Sintang dalam mengikuti pemilihan umum dikarenakan media sosialisasi pemilu yang digunakan sangat sesuai dengan karakteristik siswa sehingga media tersebut dapat menarik dan berpengaruh terhadap minat siswa dalam menggunakan media sosialisasi dan akhirnya akan berdampak kepada meningkatnya minat mereka dalam mengikuti pemilihan umum yang akan diselenggarakan oleh KPU. Hal tersebut sesuai dengan yang dikemukakan oleh Crow and Crow (dalam Shaleh., A.R., dan Wahab, M.A., 2004) tentang faktor yang menjadi timbulnya minat, yaitu: (1) Dorongan dari dalam diri individu, misal dorongan untuk makan. Dorongan untuk makan akan membangkitkan minat untuk bekerja atau mencari penghasilan, minat terhadap produksi makanan dan lain-lain. Dorongan ingin tahu atau rasa ingin tahu akan membangkitkan minat untuk membaca, belajar, menuntut ilmu, melakukan penelitian dan lainlain. (2) Motif sosial, dapat menjadi faktor yang membangkitkan minat untuk melakukan sesuatu aktivitas tertentu. Minat untuk belajar atau menuntut ilmu pengetahuan timbul karena ingin mendapat penghargaan dari masyarakat, karena biasanya yang memiliki ilmu pengetahuan cukup luas (orang pandai) mendapat kedudukan yang tinggi dan terpandang dalam masyarakat. (3) Faktor emosional, minat mempunyai hubungan yang 
erat dengan emosi. Bila seseorang mendapatkan kesuksesan pada aktivitas akan menimbulkan perasaan senang, dan hal tersebut akan memperkuat minat terhadap aktivitas tersebut, sebaliknya suatu kegagalan akan menghilangkan minat terhadap hal tersebut.

Sebagaimana Crow and Crow, Daryanto (2016) juga menyebutkan tentang fungsi media sebagai berikut: (1) Menyaksikan benda dan makhluk hidup yang ada di masa lamoau, sukar didapat dan sukar diamati secara langsung, (2) Mendengar suara yang sukar ditangkapmdengan telinga secara langsung, (3) Mengamati peristiwa-peristiwa yang jarang terjadi atau terjadi di masa lampau, (4) Dengan mudah membandingkan sesuatu, (5) Dapat melihat secara cepat suatu proses yang berlangsug secara lambat, atau sebaliknya, (6) Mengamati gerakan-gerakan mesin/alat yang sukar diamati secara langsung, (7) Melihati bagian-bagian yang tersembunyi dari suatu alat, (8) Dapat menjangkau audien yang besar jumlahnya dan mengamatyi suatu objek secara serempak, (9) dan Dapat belajar sesuai dengan kemampuan, minat dan temponya masingmasing

Berdasarkan hasil angket, maka dapat ditarik kesimpulan bahwa siswa di sekolah menengah kejuruan (SMK) di Sintang telah mempunyai sikap kesadaran dan sikap positif yang sangat baik terhadap pemilu. Hal ini dikarenakan media adobe flash yang digunakan sudah sesuai dengan karakteristik siswa di sekolah menengah kejuruan (SMK) di Sintang, hal tersebut dilihat dari muatan materi soialisasi yang disampaikan yaitu lebih berorientasi untuk membangun pemahaman, kesadaran kepada siswa di sekolah menengah kejuruan (SMK) di Sintang yaitu tentang pentingnya peran pemuda dalam kegiatan demokrasi, serta pemuda merupakan pilar penting kesuksesan suatu wilayah sehingga partisipasi mereka sangat penting untuk memilih pemimpin yang akan menetukan arah pembangunan Bangsa.

Hasil sosialisasi siswa di sekolah menengah kejuruan (SMK) di Sintang (peserta didik) di SMK Muhammadiyah Sintang menggunakan media adobe flash telah sesuai dengan tujuan dari kegiatan pendidikan politik pada siswa di sekolah menengah kejuruan (SMK) di Sintang yang ditetapkan oleh KPU, antara lain: (1) Membangun kesadaran dan pemikiran kritis para pemilih muda untuk memilih dan berpartisipasi menyelenggarakan pemilu yang bersih dan anti politik uang lewat pendidikan politik, (2) Memberi informasi terkait prosedur memilih (bagaimana cara memilih, bagaimana memastikan diri terdaftar di DPT, bagaimana cara mengecek rekam jejak caleg, dan lainlainnya), dan (3) Membuka wawasan siswa di sekolah menengah kejuruan (SMK) di Sintang tentang berbagai isu kepemiluan seperti $e$ government, peranan media sosial dalam politik dan pemilu, pelanggaran pemilu, dan daftar pemilih tetap (Sekretariat Jenderal KPU Biro Teknis dan Hupmas, 2010).

Menurut Stein, and Howard E (2003, p.39) Kesadaran diri adalah kemampuan untuk mengenali perasaan dan mengapa seseorang merasakannya seperti itu dan pengaruh perilaku seseorang terhadap orang lain. Kemampuan tersebut diantaranya; kemampuan menyampaikan secara jelas pikiran dan perasaan seseorang, membela diri dan mempertahankan pendapat (sikap asertif), kemampuan untuk mengarahkan dan mengendalikan diri dan berdiri dengan kaki sendiri (kemandirian), kemampuan untuk mengenali kekuatan dan kelemahan orang dan menyenangi diri sendiri meskipun seseorang memiliki kelemahan (penghargaan diri), serta kemampuan mewujudkan potensi yang seseorang miliki dan merasa senang (puas) dengan potensi yang seseorang raih di tempat kerja maupun dalam kehidupan pribadi (aktualisasi).

Shomali (dalam Shaleh., A.R., dan Wahab, M.A., 2004) memaparkan manfaat kesadaraan diri yang terangkum dalam enam bagian yaitu: (1) Kesadaran diri adalah alat kontrol kehidupan. Yang paling penting dalam konteks ini adalah seorang Mukmin bisa tahu bahwa ia adalah ciptaan Tuhan yang sangat berharga dan tidak melihat dirinya sama seperti hewan lain yang hanya memiliki kebutuhan dasar untuk dipuaskan dan diperjuangkan, (2) Mengenal berbagai katateristik fitrah eksklsif yang memungkinkan orang melihat dengan siapa mereka. (3) Mengetahui aspek ruhani dari wujud kita, Ruh kita bukan saja dipengaruhi 
oleh amal perbuatan kita, tetapi juga oleh gagasangagasan kita, (4) Memahami bahwa kita tidak diciptakan secara kebetulan. Dalam memahami manfaatnya, mekanisme proses alami manusia yang senantiasa mencari alasan bagi keberadaan hidupnya. Melalui kesadaran diri, perenungan dan tujuan penciptaan, orang akan sadar bahwa pribadi masing-masing itu unik (berbeda satu sama lain) dengan satu misi dalam kehidupan, dan (5) Manusia akan memperoleh bantuan besar dalam menghargai unsur kesadaran dengan benar dan kritis terhadap proses perkembangan dan penyucian ruhani.

\section{SIMPULAN DAN SARAN}

\section{Simpulan}

Desain pesan yang digunakan dalam pengembangan adobe flash untuk sosialisasi siswa di sekolah menengah kejuruan (SMK) di Sintang menggunakan langkah-langkah penelitian Borg \& Gall yang telah dilakukan sesuai dengan urutan pelaksanaanya, Pelaksanaan sosialisasi siswa di sekolah menengah kejuruan (SMK) di Sintang di SMK Muhammadiyah Sintang menggunakan adobe flash masuk dalam katagori sangat sesuai (SS), Minat siswa di sekolah menengah kejuruan (SMK) di Sintang terhadap pemilihan umum di SMK Muhammadiyah Sintang setelah menggunakan adobe flash masuk dalam katagori Baik (B), dan Sikap kritis siswa di sekolah menengah kejuruan (SMK) di Sintang untuk menumbuhkan kesadaran dan sikap positif terhadap pemilu setelah menggunakan adobe flash masuk dalam katagori sangat sesuai (SS).

\section{Saran}

Berdasarkan kesimpulan tersebut, peneliti mencoba untuk memberikan saran dengan harapan dapat memberikan masukan kepada orang yang berhubungan dengan penelitian ini. sebagai berikut: (1) Diharapkan KPU Kabupaten Sintang mendesain media yang akan digunakan sosialisasi siswa di sekolah menengah kejuruan (SMK) di Sintang pada pemilihan umum yang sesuai dengan karakteristik siswa di sekolah menengah kejuruan (SMK) di Sintang. Hal ini dikarenakan menurut hasil penelitian desain media sosialisasi siswa di sekolah menengah kejuruan (SMK) di Sintang pada pemilihan umum yang baik akan memudahkan siswa di sekolah menengah kejuruan (SMK) di Sintang dalam memahami materi pemihan umum, dibandingkan sosialisasi siswa di sekolah menengah kejuruan (SMK) di Sintang pada pemilihan umum yang hanya menggunakan modul, (2) Diharapkan KPU Kabupaten Sintang menggunakan media sosialisasi siswa di sekolah menengah kejuruan (SMK) di Sintang pada pemilihan umum yang lebih intaraktif dan sesuai dengan karakteristik peserta didik. Hal ini bertujuan agar siswa di sekolah menengah kejuruan (SMK) di Sintang lebih antusias dan semangat dalam pelaksanaan sosialisasi pemilihan umum, dikarenakan media sosialisasi pemilihan umum mudah digunakan, menyenangkan dan mempermudah untuk memahami konsep pemilihan umum, (3) Minat siswa di sekolah menengah kejuruan (SMK) di Sintang terhadap pemilihan umum sangat penting. Hal ini dikarenakan dengan meningkatnya minat siswa di sekolah menengah kejuruan (SMK) di Sintang, maka minat belajar materi pemilihan umum dan partipasi mengikuti proses pemilihan umum pemilu siswa di sekolah menengah kejuruan (SMK) di Sintang juga akan meningkat. Oleh karena itu diharapkan kepada KPU Kabupaten Sintang menggunakan media sosialisasi siswa di sekolah menengah kejuruan (SMK) di Sintang pada pemilihan umum yang sesuai dengan yang dibutuhkan oleh siswa di sekolah menengah kejuruan (SMK) di Sintang, sehingga para siswa di sekolah menengah kejuruan (SMK) di Sintang merasa sangat senang dalam pelaksanaan sosialisasi, tidak menimbulkan kebosanan, mempermudah peserta didik dalam memahami konsep pemilihan umum, dan (4) Sikap kritis siswa di sekolah menengah kejuruan (SMK) di Sintang sangat penting untuk kesuksesan suatu wilayah dalam memilih dan menentukan pemimpin yang akan menentukan arah pembangunan Bangsa. Oleh karena itu diharapkan kepada KPU Kabupaten Sintang membuat media sosialisasi siswa di sekolah menengah kejuruan (SMK) di Sintang pada pemilu dan melaksanakan proses sosialisasi pemilihan umum yang dapat meningkatkan sikap 
kritis siswa di sekolah menengah kejuruan (SMK) di Sintang, bukan hanya media sosialisasi yang bertujuan agar siswa di sekolah menengah kejuruan (SMK) di Sintang dapat memahami materi pemilihan umum saja.

\section{DAFTAR RUJUKAN}

Daryanto, (2016), Media Pembelajaran. Yogyakarta: Gava Media.

Prawidilaga, Dewi Salma. (2012). Wawasan Teknologi Pendidikan. Jakarta: Kencana.

Punaji, Setyosari, (2015), Metode Penelitian Pendidikan dan Pengembangan. Jakarta: Kencana Prenada Media Group.

Sardiman A.M, 2006, Interaksi dan Motivasi Belajar Mengajar, Jakarta: Rajagrafindo Persada.
Sekretariat Jenderal KPU Biro Teknis dan Hupmas, (2010) "Modul: Pemilu untuk Pemula". Jakarta: Penerbit Komisi Pemilihan Umum.

Shaleh., A.R., dan Wahab, M.A., 2004,p. 264, (2004) Psiklogi Suatu Pengantar, Jakarta: Kencana.

Slameto, (2010), Belajar dan faktor-faktor yang Mempengaruhinya. Jakarta: PT. Rineka Cipta

Steven J. Stein, and Book, Howard E, (2003) Ledakan EQ : 15 Prinsip Dasar Kecerdasan Emosional Meraih Sukses, Bandung: Kaifa.

Tim Sekretariat KPU Provinsi Kalimantan Barat, (2019), Modul relawan demokrasi pemilu. Pontianak: Komisi Pemilihan Umum Provinsi Kalimantan Barat. 